\title{
Evaluating the Impact of Different Tillage Regimes and Nitrogen Levels on Yield and Yield Components of Maize (Zea mays L.)
}

\author{
Muhammad Naeem Shahid, M. Shahid Ibni Zamir*, Ihtisham-Ul-Haq, M. Kamran Khan, \\ Mazhar Hussain, Usman Afzal, M. Asim, Ihtisham Ali \\ Department of Agronomy, University of Agriculture, Faisalabad, Pakistan

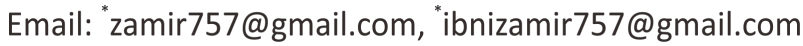

Received 22 July 2015; accepted 17 April 2016; published 20 April 2016

Copyright (C) 2016 by authors and Scientific Research Publishing Inc.

This work is licensed under the Creative Commons Attribution International License (CC BY). http://creativecommons.org/licenses/by/4.0/

(c) (i) Open Access

\begin{abstract}
A field study to evaluate the impact of different tillage regimes and nitrogen levels on yield and yield components of maize (Zea mays L.), was conducted during autumn 2014 at Students Farm, Department of Agronomy, University of Agriculture, Faisalabad. The experiment was laid out in RCBD (Randomized Complete Block Design), with split plot arrangement having three replications. The experiment was comprised of three tillage regimes (Minimum, Conventional and Deep) and three nitrogen levels viz: 100, 200 and $300 \mathrm{~kg} \cdot \mathrm{ha}^{-1}$. Urea was used as a source of nitrogen, sulphate of potash as a source of potassium and triple super phosphate as a source of phosphorous. The amount of phosphorous and potash was constant in all the treatments i.e. $125 \mathrm{~kg} \cdot \mathrm{ha}^{-1}$ and $100 \mathrm{~kg} \cdot \mathrm{ha}^{-1}$ respectively. Results of present study are summarized as yield parameters are significantly affected by different nitrogen levels and tillage regimes. Maximum number of plants at harvest (7.93), number of grain rows per cob (17.70), number of grains per row (34.31), number of grains per cob (678.58), and cob weight (187.50 g) were observed in deep tillage at $200 \mathrm{~kg} \cdot \mathrm{ha}^{-1}$ nitrogen application. 1000grain weight (275.52 g), biological yield (15.66 t.ha-1), grain yield $\left(6.16 \mathrm{t} \cdot \mathrm{ha}^{-1}\right)$ and dried stalk yield (9.91 th ha-1) were observed maximum in deep tillage at $200 \mathrm{~kg} \cdot \mathrm{ha}^{-1}$ nitrogen application. Harvest index significantly affected by tillage regimes and maximum harvest index $(39.58 \%)$ were recorded in deep tillage which was statistically at par with conventional tillage $(38.83 \%)$. It was concluded that higher grain yield of maize can be obtained by deep tillage with the application of $200 \mathrm{~kg} \cdot \mathrm{ha}^{-1}$ nitrogen application under the prevailing conditions of Faisalabad.
\end{abstract}

\section{Keywords}

Tillage Regimes, Nitrogen Levels, Deep Tillage, Biological Yield, Harvest Index

${ }^{*}$ Corresponding author.

How to cite this paper: Shahid, M.N., Zamir, M.S.I., Ul-Haq, I., Khan, M.K., Hussain, M., Afzal, U., Asim, M. and Ali, I. (2016) Evaluating the Impact of Different Tillage Regimes and Nitrogen Levels on Yield and Yield Components of Maize (Zea mays L.). American Journal of Plant Sciences, 7, 789-797. http://dx.doi.org/10.4236/ajps.2016.76073 


\section{Introduction}

Maize (Zea mays L.) is a vital cereal crop of Pakistan and grown all over the world after rice and wheat maize ranks third among cereals. Within all provinces of Pakistan Maize is grown, but Punjab and Khyber Pakhtun Khwa are the core areas of production. It contributes about $2.1 \%$ to the value added in agriculture and $0.4 \%$ to the GDP of Pakistan. Maize was cultivated on an area of 1117 thousand hectares in 2013-14, which was 5.4\% more than last year area of 1060 thousand hectares. The production of maize stood at 4527 thousand tones during 2013-14, which was 7.3\% more against last year production of 4220 thousand tones [1]. About $90 \%$ of maize is used for making feed for animals and other industrial products in highly developed countries. Commonly, it is a tropical plant but at this time it is also cultivated in subtropical and temperate regions. It is cultivated twice in a year in spring as well as in the fall season and occupies a better position in present cropping scheme. Maize grain contains starch $72 \%$, protein $10 \%$, oil $4.8 \%$, fiber $5.8 \%$, sugar $3.0 \%$ and ash $1.7 \%$. After wheat as well as rice, it is used as a staple food and it grows more in other countries as compared to other cultivated crops [2].

Production potential of Maize is quite high but production in Pakistan is so low than other developed countries. Main reasons for declining the productivity of maize include several factors, the most important are depletion of nutrients in soil, declining of soil fertility, excessive tillage, and unbalanced use of fertilizers. Tillage regimes are an integral constituent of crop production affecting numerous factors which is very important for normal crop growth. In recent times, mostly farmer's move towards conservation tillage system owing to diversity of reasons, which include soil and water conservation, saving of fuel energy and control of soil erosion [3].

In case of conventional tillage, significantly highest biological yield was obtained as compared to reduced tillage or no tillage which showed less biological and grain yield due to higher weed density [4]. Plant height was increased due to sub soiling up to depth of 50 - $55 \mathrm{~cm}$ and consequently about $9.7 \%-13.5 \%$ increase in maize yield [5]. Similarly deep ploughing with chisel plough gave higher grain yield in maize as compared with mould board plough [6].

Suitable tillage operations are desired for improvement of the soil structure and better production of the crop and as a result yield increases. Proper tillage operations improve physical properties of soil while unsuitable, unnecessary and excessive tillage operations may not provide the desired results and hence significantly decreases the crop yield [7].

Tillage also exerts negative effects on soil when the moisture condition is inadequate or when inadequate tillage implements are used. Tillage plays vital role in breaking the hardpan of subsoil layer which is created due to repeated tillage practices at the same depth year after year and resulted improving crop yield. The hard pan which is present in sub soil had negative effect on bulk density of soil, soil nutrient status, penetration resistance and soil porosity which directly or indirectly affects the yield of crops by increasing soil bulk density and decreasing soil porosity [8].

In Pakistan due too many constrains, the production potential of crop is not being dominated well enough, proper supply of nutrients is of much importance in this regard [9]. Similarly, poor fertility status of our soils is another important cause of low productivity. So, the chemical fertilizer use come into view as the quickest and easiest way for increasing agricultural production in soil where nutrient is in deficient quantity. Nitrogen is very important nutrient for crop growth and development however mainly nitrogen is lost in the shape of leaching, denitrification or volatilization if not managed properly. Nitrogen application had significant impact on plant height, number of grains per cob and 1000-grain weight [10]. [11] concluded that maximum plant height, leaf area index and accumulation of dry matter were recorded by means of increasing application of nitrogen. In the whole growing period of maize, the prescribed amount of nitrogen modified the yields and dry matter [12]. Application of nitrogen at higher rate which leads to the development of leaf area more rapidly, improves leaf area duration and increases crop net assimilation rate, consequently these factors contribute towards yield [13].

The present study was designed to find out the impact of tillage regimes on nitrogen application rates and to inspect the contact of different levels of nitrogen application within these tillage systems on the productivity of maize.

\section{Materials and Methods}

The experiment was conducted on a clay loam soil at the research Area of the Department of Agronomy, university of Agriculture, Faisalabad (Pakistan). The climate of the region is semi-arid and subtropical. The experimental area is located at $73^{\circ}$ East longitude, $31^{\circ}$ North latitude and at an altitude of 135 meters above sea level. The experiment was laid out in RCBD (Randomized Complete Block Design) with split plot arrangement hav- 
ing three replications using the net plot size of $3.0 \mathrm{~m} \times 5.0 \mathrm{~m}$. Each plot was consist of 5 rows having row to row distance of $60 \mathrm{~cm}$ and plant to plant distance of $20 \mathrm{~cm}$. The experiment was comprised of following treatments. Factor A: (Tillage Regimes) and treatments are $\mathrm{T}_{1}$ = Minimum Tillage (one cultivation followed by planking), $\mathrm{T}_{2}$ $=$ Conventional tillage (three cultivation followed by planking) and $\mathrm{T}_{3}=$ Deep Tillage (two deep ploughing with chisel plough + one cultivation followed by planking). Factor B: (Nitrogen Levels $\mathrm{kg} \cdot \mathrm{ha}^{-1}$ ) and the treatments are $N_{1}=100 \mathrm{~kg} \cdot \mathrm{ha}^{-1}, \mathrm{~N}_{2}=200 \mathrm{~kg} \cdot \mathrm{ha}^{-1}, \mathrm{~N}_{3}=300 \mathrm{~kg} \cdot \mathrm{ha}^{-1}$. The crop was sown during $2^{\text {nd }}$ week of August. Maize hybrid DK-6789 was used the test variety. The crop was sown by using seed rate of $25 \mathrm{~kg} \cdot \mathrm{ha}^{-1}$. All other agronomic practices was kept normal and uniform. Gap filling was done after 10 days of sowing while thinning was done after 30 days of sowing. Hoeing was done twice i.e. 25 and 45 days after sowing of crop to curtail the weed problem. Pesticide spray was done according to the requirement of crop. Data collected on all parameters was analyzed statistically by using Fisher's analysis of variance technique and least significant difference (LSD) test at $5 \%$ probability level was applied to compare the treatment means [14].

\section{Results and Discussions}

The data presented in Table 1 and Table 2 showed that different nitrogen levels and tillage regimes significantly affected the Yield parameters such as number of plants at harvest $\left(\mathrm{m}^{-2}\right)$, number of grains per cob, cob weight (g), 1000-grain weight, Biological yield $\left(\mathrm{t} \cdot \mathrm{ha}^{-1}\right)$, Grain yield $\left(\mathrm{t} \cdot \mathrm{ha} \mathrm{t}^{-1}\right)$, and dried stalk yield $\left(\mathrm{t} \cdot \mathrm{ha} \mathrm{a}^{-1}\right)$ were significantly affected by nitrogen levels and tillage regimes. While number of grains per row were significantly affected by nitrogen and harvest index were significantly affected by tillage regimes.

Table 1. Growth and yield related parameters of maize as influenced by different nitrogen levels under different tillage regimes.

\begin{tabular}{|c|c|c|c|c|c|c|}
\hline Treatment & $\begin{array}{c}\text { Number of } \\
\text { plants at harvest }\left(\mathrm{m}^{-2}\right)\end{array}$ & $\begin{array}{c}\text { Plant } \\
\text { height }(\mathbf{c m})\end{array}$ & $\begin{array}{l}\text { Number of } \\
\text { cobs per plant }\end{array}$ & $\begin{array}{l}\text { Number of } \\
\text { lines per cob }\end{array}$ & $\begin{array}{c}\text { Number of } \\
\text { grains per row }\end{array}$ & $\begin{array}{c}\text { Number of } \\
\text { grains per cob }\end{array}$ \\
\hline \multicolumn{7}{|c|}{ Tillage Regimes } \\
\hline $\mathbf{T}_{1}$ & $7.12 \mathrm{C}$ & 181.37 & 1.20 & $13.90 \mathrm{C}$ & 31.57 & $500.22 \mathrm{C}$ \\
\hline $\mathbf{T}_{2}$ & $7.72 \mathrm{~B}$ & 198.75 & 1.31 & $15.40 \mathrm{~B}$ & 32.12 & $578.50 \mathrm{~B}$ \\
\hline $\mathbf{T}_{3}$ & $7.93 \mathrm{~A}$ & 203.66 & 1.40 & $16.80 \mathrm{~A}$ & 32.52 & $638.58 \mathrm{~A}$ \\
\hline LSD value & 0.18 & $\ldots$ & $\ldots$ & 0.41 & $\ldots$ & 59.20 \\
\hline F value & $79.60^{*}$ & $75.84 \mathrm{NS}$ & $1.88 \mathrm{NS}$ & $201.01^{*}$ & $2.27 \mathrm{NS}$ & $21.17^{*}$ \\
\hline \multicolumn{7}{|c|}{ Nitrogen Levels } \\
\hline $\mathbf{N}_{1}$ & $7.30 \mathrm{C}$ & 185.40 & 1.27 & 14.37 C & $29.72 \mathrm{~B}$ & $519.61 \mathrm{C}$ \\
\hline $\mathbf{N}_{2}$ & $7.83 \mathrm{~A}$ & 200.27 & 1.36 & $16.53 \mathrm{~A}$ & $32.18 \mathrm{AB}$ & $624.78 \mathrm{~A}$ \\
\hline $\mathbf{N}_{3}$ & $7.64 \mathrm{~B}$ & 198.10 & 1.29 & $15.24 \mathrm{~B}$ & $34.31 \mathrm{~A}$ & $572.89 \mathrm{~B}$ \\
\hline LSD value & 0.09 & $\ldots$ & $\ldots$ & 0.83 & 2.66 & 42.98 \\
\hline F value & $73.70^{* *}$ & $10.40 \mathrm{NS}$ & $0.43 \mathrm{NS}$ & $15.90^{*}$ & $16.16^{*}$ & $14.21^{*}$ \\
\hline \multicolumn{7}{|c|}{$\mathbf{T} \times \mathbf{N}$} \\
\hline $\mathbf{T}_{1} \mathbf{N}_{1}$ & 6.95 & 163.70 & 1.13 & 12.93 & 29.77 & 441.33 \\
\hline $\mathbf{T}_{1} \mathbf{N}_{2}$ & 7.30 & 191.63 & 1.27 & 14.73 & 35.50 & 552.33 \\
\hline $\mathbf{T}_{1} \mathbf{N}_{3}$ & 7.11 & 188.77 & 1.20 & 14.00 & 34.43 & 507.00 \\
\hline $\mathbf{T}_{2} \mathbf{N}_{1}$ & 7.46 & 192.25 & 1.33 & 14.80 & 29.00 & 536.49 \\
\hline $\mathbf{T}_{2} \mathbf{N}_{2}$ & 7.94 & 203.00 & 1.33 & 15.86 & 32.74 & 610.00 \\
\hline $\mathbf{T}_{2} \mathbf{N}_{3}$ & 7.77 & 201.00 & 1.27 & 15.53 & 34.63 & 589.00 \\
\hline $\mathbf{T}_{3} \mathbf{N}_{1}$ & 7.49 & 200.27 & 1.33 & 14.40 & 30.06 & 582.00 \\
\hline $\mathbf{T}_{3} \mathbf{N}_{2}$ & 8.26 & 206.17 & 1.47 & 19.00 & 33.30 & 712.00 \\
\hline $\mathbf{T}_{3} \mathbf{N}_{3}$ & 8.05 & 204.53 & 1.40 & 16.20 & 34.20 & 622.68 \\
\hline LSD value & $\ldots$ & $\ldots$ & $\ldots$ & $\ldots$ & $\ldots$ & $\cdots$ \\
\hline F value & 5.07NS & 2.07NS & $0.07 \mathrm{NS}$ & $2.62 \mathrm{NS}$ & $0.92 \mathrm{NS}$ & $0.63 \mathrm{NS}$ \\
\hline
\end{tabular}

${ }^{*}=$ Significant at $p \leq 0.05 ;{ }^{* *}=$ Significant at $\mathrm{p} \leq 0.01 ; \mathrm{NS}=$ Non-significant; $\mathrm{T}=$ Tillage Regimes; $\mathrm{N}=$ Nitrogen Levels; $\mathrm{T}_{1}=$ Minimum Tillage; $\mathrm{T}_{2}=$ Conventional Tillage.; $\mathrm{T}_{3}=$ Deep Tillage; $\mathrm{N}_{1}=100 \mathrm{~kg} \cdot \mathrm{ha}^{-1} ; \mathrm{N}_{2}=200 \mathrm{~kg} \cdot \mathrm{ha}^{-1} ; \mathrm{N}_{3}=300 \mathrm{~kg} \cdot \mathrm{ha}^{-1}$. Means not sharing the same letter in common differ significantly at $5 \%$ probability level. 
Table 2. Growth and yield related parameters of maize as influenced by different nitrogen levels under different tillage regimes.

\begin{tabular}{|c|c|c|c|c|c|c|}
\hline Treatment & Cob weight (g) & $\begin{array}{l}\text { 1000-grain } \\
\text { weight (g) }\end{array}$ & $\begin{array}{c}\text { Biological } \\
\text { yield }\left(t \cdot h a^{-1}\right)\end{array}$ & $\begin{array}{c}\text { Grain yield } \\
\left(t \cdot h a^{-1}\right)\end{array}$ & $\begin{array}{c}\text { Dried stalk } \\
\text { yield }\left(t \cdot h a^{-1}\right)\end{array}$ & $\begin{array}{c}\text { Harvest } \\
\text { Index (\%) }\end{array}$ \\
\hline \multicolumn{7}{|c|}{ Tillage Regimes } \\
\hline $\mathbf{T}_{1}$ & $153.56 \mathrm{C}$ & 243.97 B & $8.01 \mathrm{C}$ & $2.67 \mathrm{C}$ & $5.00 \mathrm{~B}$ & 32.77 B \\
\hline $\mathbf{T}_{2}$ & 168.77 B & $257.96 \mathrm{AB}$ & $11.01 \mathrm{~B}$ & $4.28 \mathrm{~B}$ & $7.12 \mathrm{~A}$ & $38.83 \mathrm{~A}$ \\
\hline $\mathbf{T}_{3}$ & $177.61 \mathrm{~A}$ & $274.37 \mathrm{~A}$ & $13.29 \mathrm{~A}$ & $5.21 \mathrm{~A}$ & $7.65 \mathrm{~A}$ & $39.58 \quad \mathrm{~A}$ \\
\hline LSD value & 3.19 & 8.93 & 0.88 & 0.59 & 0.89 & 3.40 \\
\hline F value & $254.38^{*}$ & $5.32^{*}$ & $136.03^{* *}$ & $71.83^{*}$ & $38.30^{*}$ & $14.07^{*}$ \\
\hline \multicolumn{7}{|c|}{ Nitrogen Levels } \\
\hline $\mathbf{N}_{1}$ & 157.09 C & 235.98 B & $8.81 \mathrm{C}$ & $3.17 \mathrm{C}$ & $5.82 \mathrm{~B}$ & 35.54 \\
\hline $\mathbf{N}_{2}$ & 173.76 A & $275.52 \mathrm{~A}$ & $12.51 \mathrm{~A}$ & $4.72 \mathrm{~A}$ & $7.54 \mathrm{~A}$ & 38.77 \\
\hline $\mathbf{N}_{3}$ & 168.89 B & 264.79 АВ & $11.01 \mathrm{~B}$ & $4.26 \mathrm{~B}$ & $6.41 \mathrm{~B}$ & 36.89 \\
\hline LSD value & 2.66 & 8.89 & 0.63 & 0.26 & 0.88 & \\
\hline F value & $93.87^{* *}$ & $4.72^{*}$ & $80.77^{* *}$ & $89.00^{* *}$ & $9.18^{*}$ & $1.90 \mathrm{NS}$ \\
\hline \multicolumn{7}{|c|}{$\mathbf{T} \times \mathbf{N}$} \\
\hline $\mathbf{T}_{1} \mathbf{N}_{1}$ & $146.07 \mathrm{~g}$ & 228.18 & $6.97 \mathrm{f}$ & $2.20 \mathrm{f}$ & $4.42 \mathrm{e}$ & 31.44 \\
\hline $\mathbf{T}_{1} \mathbf{N}_{2}$ & $157.00 \mathrm{ef}$ & 255.10 & 8.95 de & $3.04 \mathrm{e}$ & $5.35 \mathrm{de}$ & 33.06 \\
\hline $\mathbf{T}_{1} \mathbf{N}_{3}$ & $154.53 \mathrm{f}$ & 248.63 & 8.19 e & $2.77 \mathrm{e}$ & $5.22 \mathrm{de}$ & 33.80 \\
\hline $\mathbf{T}_{2} \mathbf{N}_{1}$ & $159.73 \mathrm{~g}$ & 237.47 & $9.46 \mathrm{~d}$ & 3.44 de & $7.92 \mathrm{~b}$ & 35.51 \\
\hline $\mathbf{T}_{2} \mathbf{N}_{2}$ & $175.80 \mathrm{c}$ & 272.52 & $12.93 \mathrm{c}$ & $4.98 \mathrm{~b}$ & $7.36 \mathrm{bc}$ & 38.21 \\
\hline $\mathbf{T}_{2} \mathbf{N}_{3}$ & 171.37 c & 263.88 & $10.65 \mathrm{~d}$ & $4.42 \mathrm{c}$ & $6.08 \mathrm{~cd}$ & 42.77 \\
\hline $\mathbf{T}_{3} \mathbf{N}_{1}$ & $165.31 \mathrm{~d}$ & 242.30 & $10.01 \mathrm{~cd}$ & $3.88 \mathrm{~cd}$ & $5.11 \mathrm{de}$ & 39.65 \\
\hline $\mathbf{T}_{3} \mathbf{N}_{2}$ & $187.50 \mathrm{a}$ & 298.95 & $15.66 \mathrm{a}$ & $6.16 \mathrm{a}$ & $9.91 \mathrm{a}$ & 39.36 \\
\hline $\mathbf{T}_{3} \mathbf{N}_{3}$ & $181.17 \mathrm{~b}$ & 281.87 & $14.18 \mathrm{~b}$ & $5.60 \mathrm{~b}$ & $7.94 \mathrm{~b}$ & 39.73 \\
\hline LSD value & 4.62 & $\ldots$ & 1.10 & 0.45 & 1.54 & $\ldots$ \\
\hline F value & $3.29^{*}$ & $0.23 \mathrm{NS}$ & $8.96^{*}$ & $6.92^{*}$ & $9.3^{*}$ & $0.85 \mathrm{NS}$ \\
\hline
\end{tabular}

$\mathrm{s}^{*}=$ Significant at $p \leq 0.05 ;{ }^{* *}=$ Significant at $p \leq 0.01 ; \mathrm{NS}=$ Non-significant; $\mathrm{T}=$ Tillage Regimes; $\mathrm{N}=\mathrm{Nitrogen}$ Levels; $\mathrm{T}_{1}=$ Minimum Tillage; $\mathrm{T}_{2}$ = Conventional Tillage.; $\mathrm{T}_{3}=$ Deep Tillage; $\mathrm{N}_{1}=100 \mathrm{~kg} \cdot \mathrm{ha}^{-1} ; \mathrm{N}_{2}=200 \mathrm{~kg} \cdot \mathrm{ha}^{-1} ; \mathrm{N}_{3}=300 \mathrm{~kg} \cdot \mathrm{ha}^{-1}$. Means not sharing the same letter in common differ significantly at $5 \%$ probability level.

Plant height of maize is an important part of stalk yield and may also play important role in increasing the grain yield of crop. The data regarding to plant height of maize crop are given in Table 1 . The data showed that both the tillage and different levels of Nitrogen had non-significant effect on the plant height of maize individually and in combination. Regarding the tillage maximum plant height $(203.66 \mathrm{~cm})$ were observed where deep tillage was applied followed by the $T_{2}$ (conventional tillage) and the minimum plant height $(181.37 \mathrm{~cm})$ were observed in $\mathrm{T}_{1}$ (Minimum tillage) was applied. While in case of nitrogen levels, maximum Plant height (200.27 $\mathrm{cm}$ ) was recorded in the plots where $200 \mathrm{~kg} \cdot \mathrm{ha}^{-1}\left(\mathrm{~N}_{2}\right)$ were applied followed by the plot treated with $300 \mathrm{~kg} \cdot \mathrm{ha}^{-1}$ $\left(\mathrm{N}_{3}\right)$ and the minimum Plant height $(185.40 \mathrm{~cm})$ were observed in $\left(\mathrm{N}_{1}\right)$ where minimum nitrogen $100 \mathrm{~kg} \cdot \mathrm{ha}^{-1}$ were applied. These results are in line with the finding of [15] and [16] who stated that plant height of maize increased with increase in $\mathrm{P}$ application.

Among all the yield parameters plant population is one of the most important constituent. Data given in Table 1 showed that different levels of the nitrogen and tillage had significant effect on the number of plant at harvest 
individually and in combination. Regarding the tillage maximum number of plants at harvest $\left(8.00 \mathrm{~m}^{2}\right)$ were observed where Deep tillage was applied followed by the $T_{2}$ (Conventional tillage)) and the minimum number of plants at harvest $\left(7.12 \mathrm{~m}^{2}\right.$ ) were observed in $\mathrm{T}_{1}$ (Minimum tillage) was applied. Regarding the nitrogen levels maximum number of plants $\left(7.84 \mathrm{~m}^{2}\right)$ were observed in the plots where $200 \mathrm{~kg} \cdot \mathrm{ha}^{-1}\left(\mathrm{~N}_{2}\right)$ were applied followed by the plot treated with $300 \mathrm{~kg} \cdot \mathrm{ha}^{-1}\left(\mathrm{~N}_{3}\right)$ and the minimum number of plants $\left(7.35 \mathrm{~m}^{2}\right)$ were observed in $\left(\mathrm{N}_{1}\right)$ where minimum nitrogen $100 \mathrm{~kg} \mathrm{ha}^{-1}$ were applied. These results are in line to [17] who reported that tillage systems greatly affected maize germination, its growth and development.

Number of cobs per plant is also one of the major yield contributing parameters which contributes towards final grain yield. The response of different levels of nitrogen, tillage regimes and their interaction on the number of cobs per plant of maize were found non-significant results (Table 1). But the number of cobs per plant ranged between 1.13 to 1.40 and 1.13 to 1.40 for tillage regimes and nitrogen levels respectively. Nitrogen application did not significantly affect the number of cobs per plants in maize. The reason behind these non-significant results might be that the number of cobs per plant is a genetic character of maize plants which is not affected by nitrogen application or tillage regimes. [18] who remarked that there is no effect of tillage on number of cobs per plant as it is a genetically controlled variable and it does not get varied by environment, nutrient application and tillage practices.

The number of grain rows per cob is an important yield parameter of maize crop. It directly affects the number of grains per cob and grain yield of maize. The data regarding the number of grains row per cob are given in Table 1. The data showed that both different levels of the nitrogen and tillage had significant individual effect on the number of grains row per cob. While interaction effect of both these have non-significant effect on the number of grains row per cob. In case of tillage regimes, mean value of number grains row per cob (16.80) was observed maximum where deep tillage was applied followed by the $T_{2}$ (Conventional tillage) and the minimum number of grains row per cob (13.90) was observed in $T_{1}$ where Minimum tillage was applied. These results are in accordance with [18] who reported that higher number of grain rows per cob was observed in soils where tillage was applied. While in case of levels of nitrogen, the maximum mean value of number of grains row per cob (16.53) were recorded with the application of $200 \mathrm{~kg} \cdot \mathrm{ha}^{-1}\left(\mathrm{~N}_{2}\right)$ followed by the plot treated with $300 \mathrm{~kg} \cdot \mathrm{ha}^{-1}\left(\mathrm{~N}_{3}\right)$, where grain rows per cob were recorded as (15.24) while the minimum number grains row per cob (14.37) were observed in those plots where nitrogen was applied at the rate of $100 \mathrm{~kg} \cdot \mathrm{ha}^{-1}\left(\mathrm{~N}_{1}\right)$. The increase in number of grains per row might be due to optimum dose of nitrogen, which plays an important role in tissue development, cell division, enhance plant growth and thereby increased number of grains row per cob. Similar results were reported by [19] and [20]. These results were also similar with that of [21] and Leon [22] who reported that number of grains $\mathrm{cob}^{-1}$ were influenced significantly with NP application.

The number of grains per row is also an important yield parameter of maize crop. Table 1 showed statistically significant effect of nitrogen application on number of grains per row while tillage regimes did not significantly affect the number of grains per row. Among the nitrogen levels the maximum grains per rows (34.31) were observed at $300 \mathrm{~kg} \cdot \mathrm{ha}^{-1}$ nitrogen level which was at par with (32.18) for $200 \mathrm{~kg} \mathrm{~N} \mathrm{ha}{ }^{-1}$. The minimum grains per row (29.72) were recorded in those plots where nitrogen was applied at the rate of $100 \mathrm{~kg} \cdot \mathrm{ha}^{-1}$ and was at par with treatment $200 \mathrm{~kg} \cdot \mathrm{ha}^{-1}$ nitrogen level. The reason for more number of grains per row more nitrogen availability to plants for growth and development. These results are in agreement with [23] and [24] who reported that increment in nitrogen level increased grain rows per cob. The increase in number of grains per row might be due to optimum dose of nitrogen, which plays an important role in tissue development, cell division, enhance plant growth and thereby increased number of grains per row. Similar results were reported by [19] and [20].

The number of grains per cob is also an imperative factor, which contribute significantly towards grain yield of maize crop. If the number of grains per cob is more, the yield will be high.

The data pertaining to total number of grains per cob are given in the Table 1 . The data showed that both different levels of the nitrogen and tillage have significant individual effect on total number of grains per cob. While interaction of both these factors had non-significant effect on total number of grains per cob. Regarding tillage regimes, mean value of number grains per cob (638.58) were observed maximum where deep tillage was applied followed by the $T_{2}$ (Conventional tillage) and the minimum number of grains per cob (500.22) was observed in $\mathrm{T}_{1}$ where Minimum tillage was applied. [25] who reported that plant height, number of grains per cob were reduced in case of zero tillage as compared to conventional tillage. Similar results were also found by [26] who stated that tillage has significant effect on the number of grains per cob. These results are contradictory to [4] who reported that there is no significant difference among tillage practices on number of grains per cob. As 
for as levels of nitrogen, the maximum mean value of number of grains per cob (624.78) was observed where $200 \mathrm{~kg} \cdot \mathrm{ha}^{-1}\left(\mathrm{~N}_{2}\right)$ was applied which was followed by the plot treated with $300 \mathrm{~kg} \cdot \mathrm{ha}^{-1}\left(\mathrm{~N}_{3}\right)$ and the minimum number grains per cob (519.61) were observed in $\left(\mathrm{N}_{1}\right)$ where minimum nitrogen $100 \mathrm{~kg} \cdot \mathrm{ha}^{-1}$ was applied. These results are in line with [27] who reported that increase in nitrogen level increased the number of grains per cob.

Cob weight also significantly affected the grain yield, more the weight of cob more will be the grain yield. The data regarding the cob weight are given in Table 2. The data showed that both different levels of the nitrogen and tillage had significant individual effect on the cob weight. While interaction effect of both these also had significant effect on cob weight. Data regarding the interaction effect of both treatment tillage and the different levels of nitrogen, it was reported that maximum weight of cob (187.50 g) were observed in treatment combination $\mathrm{T}_{3} \mathrm{~N}_{2}$ (Deep tillage $+200 \mathrm{~kg} \cdot \mathrm{ha}^{-1}$ ) which was followed by the $\mathrm{T}_{3} \mathrm{~N}_{3}$ (Deep tillage $+300 \mathrm{~kg} \cdot \mathrm{ha}^{-1}$ ) recorded cob weight as $(181.77 \mathrm{~g})$. The minimum weight of cob $(146.07 \mathrm{~g})$ was observed in treatment combination $\mathrm{T}_{1} \mathrm{~N}_{1}$ (minimum tillage $+100 \mathrm{~kg} \cdot \mathrm{ha}^{-1}$ ). The remaining all the treatments were also statistically different from each other.

1000-grain weight is an important yield contributing parameter which plays a decisive role in showing a potential of variety. The data pertaining the effect of different levels of nitrogen, tillage regimes and their interaction on 1000-grain weight of maize are presented in Table 2. Different levels of nitrogen and tillage regimes have significant effect on 1000-grain weight of maize. Regarding tillage, mean maximum 1000 grain weight was recorded as (274.37 g) in $\mathrm{T}_{3}$ (Deep tillage) which was statistically at par to $\mathrm{T}_{2}$ (Conventional tillage). While mean minimum 1000 grain weight was $\left(243.97 \mathrm{~g}\right.$ ) was observed in $\mathrm{T}_{1}$ (Minimum tillage). These results are in line with [25] who reported that plant height, number of grains per cob and grain weight were higher in conventional tillage as compared to zero tillage system. [28] reported that maize crop grown on deep tillage produces heavier grain weight as compared to conventional and zero tillage sown crops. So, this result is contradictory to [28]. Recording nitrogen levels, Mean maximum 1000 grain weight was recorded as $(275.52 \mathrm{~g})$ in $200 \mathrm{~kg} \cdot \mathrm{ha}^{-1}$ $\left(\mathrm{N}_{2}\right)$ which was statistically at par to $\left(\mathrm{N}_{3}\right)$ where $300 \mathrm{~kg} \cdot \mathrm{ha}^{-1}$ nitrogen was applied, while mean minimum 1000 grain weight was (235.98 g) recorded in $\mathrm{N}_{1}$ where minimum nitrogen $100 \mathrm{~kg} \cdot \mathrm{ha}^{-1}$ was applied. The increase in 1000-grain weight (g) might be due to optimum dose of nitrogen, which plays an important role in tissue development, cell division, enhance plant growth and thereby increased 1000-grain weight. Similar results were reported by [19] and [20]. This results reported by [27] and [29] were that increasing levels of nitrogen increase 1000 -grain weight which are in line with these findings.

Biological yield reflects about the total biomass obtained by the plant during its life cycle under prevailing condition(using different treatments) and it comprises of Stover and grain yield. So it is a function of the genetic makeup of the crop, environmental condition, soil nutrient status and management practices. Data regarding the biological yield of autumn maize are given in Table 2. It is clear from Table 2 that the effect of different levels of nitrogen and tillage regimes and their interaction on biological yield of maize was highly significant. As regards to tillage, mean value of biological yield $\left(177.61 \mathrm{t}^{\mathrm{ha}} \mathrm{h}^{-1}\right)$ was observed maximum where deep tillage was applied followed by the $T_{2}$ (Conventional tillage)) and the minimum biological yield (153.56 tha ${ }^{-1}$ ) was observed in $\mathrm{T}_{1}$ where minimum tillage was applied. These results are in line with who reported that in minimum tillage biological yield is lowered due to higher soil compactness and unfavorable conditions for root growth and lower nutrient uptake. According to [30] higher yield is observed in soil in which tillage is applied as compared to those in which no tillage is applied. As for as Levels of nitrogen, the maximum mean value of biological yield $\left(\left(173.76 \mathrm{t}^{\mathrm{h} a} \mathrm{H}^{-1}\right)\right.$ was observed in plot treated with $200 \mathrm{~kg} \cdot \mathrm{ha}^{-1}\left(\mathrm{~N}_{2}\right)$ followed by the plot treated with $300 \mathrm{~kg} \cdot \mathrm{ha}^{-1}$ $\left(\mathrm{N}_{3}\right)$, while the minimum biological yield $\left(157.09 \mathrm{t}^{-\mathrm{ha}^{-1}}\right)$ were observed in those plots where minimum nitrogen $100 \mathrm{~kg} \cdot \mathrm{ha}^{-1}\left(\mathrm{~N}_{1}\right)$ was applied. Data regarding the interaction effect of both treatment tillage and the different levels of nitrogen maximum biological yield $\left(187.50 \mathrm{t} \cdot \mathrm{ha}^{-1}\right.$ ) were observed in treatment combination $\mathrm{T}_{3} \mathrm{~N}_{2}$ (Deep tillage $+200 \mathrm{~kg} \cdot \mathrm{ha}^{-1}$ ) which was followed by the $\mathrm{T}_{3} \mathrm{~N}_{3}$ (Minimum Tillage $+100 \mathrm{~kg} \cdot \mathrm{ha}^{-1}$ ). The minimum biological yield (146.07 tha ${ }^{-1}$ ) was observed in treatment combination $\mathrm{T}_{1} \mathrm{~N}_{1}$ (minimum tillage $+100 \mathrm{~kg} \cdot \mathrm{ha}^{-1}$ ). The remaining all the treatments were also statistically different from each other. These results are in conformity with the study of [31] who found that maximum biological yield was found where nitrogen and phosphorous was applied at the rate of $150 \mathrm{~kg} \cdot \mathrm{ha}^{-1}$ and $200 \mathrm{~kg} \cdot \mathrm{ha}^{-1}$ respectively as compared to the low amount of the nitrogen and phosphorous was applied.

Grain yield is the end product of the crop it also called as economic yield. Grain yield obtained as a result of the interaction of the all the yield related parameters such as plant height, number of cobs per plant, number of grains per row, biological yield, biomass yield all these integrate and cause it to produce the grain yield. In addi- 
tion of these grain yield also correlated with the net assimilation rate and the with better crop growth rate. Data regarding the grain yield of autumn maize are given in Table 2. It is clear from Table 2 that the impact of different levels of nitrogen and tillage regimes on grain yield of maize was highly significant while interaction between nitrogen levels and tillage regimes was also significant. As regards to tillage regimes, mean value of grain yield $\left(5.21 \mathrm{t}^{-h a^{-1}}\right)$ was observed maximum in those plots where deep tillage was applied which was followed by the $\mathrm{T}_{2}$ (Conventional tillage)) and the minimum grain yield $\left(2.67 \mathrm{t} \cdot \mathrm{ha}^{-1}\right)$ was observed in $\mathrm{T}_{1}$ where minimum tillage was applied. These results are according to [30] who reported that maize yield is less in minimum tillage as compared to conventional tillage. These results are also supported by [32] who reported that conventional tillage systems are more productive than zero and reduced tillage systems. As for as Levels of nitrogen, the maximum mean value of grain yield $\left(4.72 \mathrm{t} \cdot \mathrm{ha}^{-1}\right)$ was observed in plot treated with $200 \mathrm{~kg} \cdot \mathrm{ha}^{-1}\left(\mathrm{~N}_{2}\right)$ followed by the plot treated with $300 \mathrm{~kg} \cdot \mathrm{ha}^{-1}\left(\mathrm{~N}_{3}\right)$ and the minimum grain yield $\left(3.17 \mathrm{t} \cdot \mathrm{a}^{-1)}\right.$ were observed in $\left(\mathrm{N}_{1}\right)$ where minimum nitrogen $100 \mathrm{~kg} \cdot \mathrm{ha}^{-1}$ was applied. Data regarding the interaction effect of both treatment tillage and the different levels of nitrogen maximum grain yield $\left(6.16 \mathrm{t}^{\mathrm{h}} \mathrm{h}^{-1}\right.$ ) were observed in treatment combination $\mathrm{T}_{3} \mathrm{~N}_{2}$ (Deep tillage + $200 \mathrm{~kg} \cdot \mathrm{ha}^{-1}$ ), followed by the $\mathrm{T}_{3} \mathrm{~N}_{3}$ (deep tillage $+300 \mathrm{~kg} \cdot \mathrm{ha}^{-1}$ ). The minimum grain yield $\left(2.20 \mathrm{t}^{-\mathrm{ha}^{-1}}\right.$ ) was observed in treatment combination $\mathrm{T}_{1} \mathrm{~N}_{1}$ (minimum tillage $+100 \mathrm{~kg} \cdot \mathrm{ha}^{-1}$ ). The remaining all the treatments were also statistically different from each other. These results were in conformity with the finding of the [33] who stated that maximum grain yield was found where the $\mathrm{N}$ and $\mathrm{P}$ was applied at the rate of $200-100 \mathrm{~kg}$ per hectare.

Dried stalk yield refers to the function of the genetic makeup of a crop, soil nutrient status and management strategies. Data regarding the biological yield of autumn maize are given in Table 2. It is clear from Table 2 that the effect of different levels of nitrogen and tillage regimes and their interaction on dried stalk yield of maize was significant. Data regarding the dried stalk by using different levels of the nitrogen and tillage significantly affected the dried stalk yield. As regards to tillage levels, mean value of dried stalk yield $\left(7.65 \mathrm{t} \cdot \mathrm{ha}^{-1}\right)$ was observed maximum where deep tillage was applied followed by the $\mathrm{T}_{2}$ (conventional tillage) and the minimum dried stalk yield $\left(5.00 \mathrm{t}^{-\mathrm{ha}^{-1}}\right.$ ) was observed in $\mathrm{T}_{1}$ where Minimum tillage was applied. As for as Levels of nitrogen, the maximum mean value of dried stalk yield $\left(7.54 \mathrm{t} \cdot \mathrm{ha}^{-1}\right)$ was observed in plot treated with $200 \mathrm{~kg} \cdot \mathrm{ha}^{-1}\left(\mathrm{~N}_{2}\right)$ followed by the plot treated with $300 \mathrm{~kg} \cdot \mathrm{ha}^{-1}\left(\mathrm{~N}_{3}\right)$ and the minimum dried stalk yield $\left(5.82 \mathrm{t} \cdot \mathrm{ha}^{-1}\right)$ were observed in $\left(\mathrm{N}_{1}\right)$ where minimum nitrogen $100 \mathrm{~kg} \mathrm{ha}^{-1}$ was applied.

Data regarding the interaction effect of both treatment tillage and the different levels of nitrogen maximum dried stalk yield $\left(9.91 \mathrm{t} \cdot \mathrm{ha}^{-1}\right.$ ) were observed in treatment combination $\mathrm{T}_{3} \mathrm{~N}_{2}$ (Deep tillage $+200 \mathrm{~kg} \cdot \mathrm{ha}^{-1}$ ) followed by the $\mathrm{T}_{3} \mathrm{~N}_{3}$ (Deep tillage $+300 \mathrm{~kg} \cdot \mathrm{ha}^{-1}$ ). The minimum dried stalk yield $\left(4.42 \mathrm{t} \cdot \mathrm{ha}^{-1}\right.$ ) was observed in treatment combination $\mathrm{T}_{1} \mathrm{~N}_{1}$ (minimum tillage $+100 \mathrm{~kg} \cdot \mathrm{ha}^{-1}$ ). The remaining all the treatments were also statistically different from each other. These results were in conformity with the study of [31] who found that maximum dried stalk yield was found where the nitrogen was applied at the rate of $200 \mathrm{~kg} \cdot \mathrm{ha}^{-1}$ as compared to the low amount of the nitrogen was applied.

The physiological effectiveness of maize crop to partition the dry matter into its cost effective (grain) yield is referred by harvest index. Superior the harvest index is better will be the efficiency of crop in partitioning dry matter to its economic portion and greater will be the grain yield. Data regarding the biological yield of spring maize are given in Table 2. It is clear from Table 2 that the effect of different tillage regimes on grain yield of maize was significant while effect of nitrogen and interaction between different nitrogen levels and tillage regimes was non-significant.

As regards to tillage regimes, mean value of harvest index (39.58) was observed maximum where deep tillage was applied followed by the $T_{2}$ (conventional tillage) and the minimum harvest index (32.77) was observed in $\mathrm{T}_{1}$ where minimum tillage was applied. These results are according to [30] who reported that maize yield is less in minimum tillage as compared to conventional tillage. As for as levels of nitrogen is concerned, the maximum mean value of harvest index (38.76) was observed in plot treated with $200 \mathrm{~kg} \cdot \mathrm{ha}^{-1}\left(\mathrm{~N}_{2}\right)$, followed by the plot treated with $200 \mathrm{~kg} \cdot \mathrm{ha}^{-1}\left(\mathrm{~N}_{3}\right)$ while the minimum harvest index (35.53) were observed in $\left(\mathrm{N}_{1}\right)$ where minimum nitrogen $100 \mathrm{~kg} \cdot \mathrm{ha}^{-1}$ was applied. These results were in line with the finding of [33] who stated that maximum harvest index was found where NP was applied at the rate of 200 and $100 \mathrm{~kg} \cdot \mathrm{ha}^{-1}$ respectively. While the interaction effect of both tillage and the different levels of nitrogen also has non-significant effect on the harvest index of the autumn maize.

\section{References}

[1] Government of Pakistan (2014) Pakistan Economic Survey 2013-14. Ministry of Finance, Economic Advisor’s Wing, 
Islamabad.

[2] Frova, C., Krajewski, P., Fonzo, N.D., Villa, M. and Sari-Gorla, M. (1999) Genetic Analysis.

[3] Torbert, H.A., Potter, K.N. and Morrison, J.E. (2001) Tillage System, Fertilizer Nitrogen Rate and Timing Effect on Corn Yield in the Taxes Black Land Prairie. Agronomy Journal, 93, 1119-1124. http://dx.doi.org/10.2134/agronj2001.9351119x

[4] Gul, B., Marwat, K.B., Hassan, G., Khan, A., Hashim, S. and Khan, I.A. (2009) Impact of Tillage, Plant Population and Mulches on Biological Yield of Maize. Pakistan Journal of Botany, 41, 2243-2249.

[5] Borghei, A.M., Taghinejad, J., Minaei, S., Karimi, M. and Varnamkhasti, M.G. (2008) Effect of Subsoiling on Soil Bulk Density, Penetration Resistance and Cotton Yield in Northwest of Iran. International Journal of Agriculture and Biology, 10, 120-123.

[6] Wasaya, A., Tahir, M., Manaf, A., Ahmed, M., Kaleem, S. and Ahmad, I. (2011) Improving Maize Productivity through Tillage and Nitrogen Management. African Journal of Biotechnology, 10, 19025-19034.

[7] Iqbal, M., Hassan, A.U., Ali, A. and Rizwanullah, M. (2005) Residual Effect of Tillage and Farm Manure on Some Soil Physical Properties and Growth of Wheat (Triticum aestivum L.). International Journal of Agriculture and Biology, 7, 54-57.

[8] Ahmad, N., Hassan, F.U. and Belford, R.K. (2009) Effect of Soil Compaction in the Sub-Humid Cropping Environment in Pakistan on Uptake of NPK and Grain Yield in Wheat (Triticum aestivum). Field Crops Research, 110, 54-60. http://dx.doi.org/10.1016/j.fcr.2008.07.001

[9] Oad, F.C., Buriro, U.A. and Agha, S.K. (2004) Effect of Organic and Inorganic Fertilizer Application on Maize Fodder Production. Asian Journal of Plant Sciences, 3, 375-377. http://dx.doi.org/10.3923/ajps.2004.375.377

[10] Mahmood, M.T., Maqsood, M., Awan, T.H., Rashid, S. and Sarwar, R. (2001) Effect of Different Levels of Nitrogen and Intra-Row Plant Spacing on Yield and Yield Components of Maize. Pakistan Journal of Agricultural Sciences, 38, 48-49.

[11] Shivay, Y.S. and Singh, R.P. (2000) Growth, Yield Attributes, Yields and Nitrogen Uptake of Maize (Zea mays L.) as Influenced by Cropping Systems and Nitrogen Levels. Annals of Agricultural Research, 21, 494-498.

[12] Scholz, G., Quinton, J.N. and Strauss, P. (2008) Soil Erosion from Sugar Beet in Central Europe in Response to Climate Change Induced Seasonal Precipitation Variations. Catena, 72, 91-105. http://dx.doi.org/10.1016/j.catena.2007.04.005

[13] Balasbrammaniyan, P. and Palaniappan, S.P. (2001) Nutrient Management. Principles and Practices of Agronomy, Agrobios India, Jodhpur, 185-188.

[14] Steel, R.G.D., Torrie, J.H. and Dickey, D.A. (1997) Principles and Procedures of Statistics: A Biometrical Approach. 3rd Systems. Revista Braseilera de Ciencia do Solo, 25, 717-723.

[15] Arain, A.S., Aslam, S.M. and Tunio, A.K.G. (1989) Performance of Maize Hybrids under Varying NP Fertilizer Environments. Sarhad Journal of Agriculture, 5, 623-626.

[16] Dodd, J. (2000) The Role of Arbuscular Mycorrhizal Fungi in Agro- and Natural Ecosystems. Outlook on Agriculture, 29, 55. http://dx.doi.org/10.5367/000000000101293059

[17] Wilhem, W.W., Johnson, J.M.F., Hatfield, J.L., Voorhees, W.B. and Linden, D.R. (2004) Crop and Soil Productivity Response to Corn Residue Removal: A Literature Review. Agronomy Journal, 96, 1-17. http://dx.doi.org/10.2134/agronj2004.0001

[18] Rashidi, M. and Keshavarzpour, F. (2007) Effect of Different Tillage Methods on Grain Yield and Yield Components of Maize (Zea mays L.). International Journal of Agriculture and Biology, 9, 274-277.

[19] Shah, S.H.A. (2001) Growth, Yield and Raditation Use Efficiency of Maize under Variable Irrigation Schedules. MSc. (Hons). Thesis, Department of Agronomy, University of Agriculture, Faisalabad.

[20] Rasheed, M. (2002) Biological Response of Hybrid Maize to Plantation Methods and Nutrient Management. PhD Thesis, Department of Agronomy, University of Agriculture, Faisalabad.

[21] Maqsood, M., Abid, A.M., Iqbal, A. and Hussain, M.I. (2001) Effect of Various Rates of Nitrogen and Phosphorus on Growth and Yield of Maize.

[22] Leon, L.A. (1999) Phosphorus and Potassium Interactions in Acid Soils of the Eastern Plains of Colombia. Better Crops International, 13, 8-10.

[23] Lambert, R.J., Hoeft, R.G., Gonzini, L.C. and Warren, L. (1998) Monitoring Nitrogen Use of Corn Hybrids Using Grain Protein Concentration. Illinois Fertilizer Conference Proceeding, 26-28 January 1998, 97-104.

[24] Zulfiqar, A. (1995) Comparative Studies on Growth and Yield Performance on Some New Maize Cultivars Planted in Different Patterns. MSc. (Hons). Agri. Thesis, Department of Agronomy, University of Agriculture, Faisalabad. 
[25] Albuquerque, J.A., Sangoi, L. and Ender, M. (2001) Modification in the Soil Physical Properties and Phosphorus on Growth and Yield of Maize. Pakistan Journal of Biological Sciences, 1, 19-20.

[26] Khan, A., Jan, M.T., Marwat, K.B. and Arif, M. (2009) Organic and Inorganic Nitrogen Treatments Effect on Plant and Yield Attributes of Maize in a Different Tillage Systems. Pakistan Journal of Botany, 41, 99-108.

[27] Gokmen, S., Sencar, O. and Sakin, M.A. (2001) Response of Popcorn (Zea mays) to Nitrogen Rates and Plant Densities. Turkish Journal of Agriculture and Forestry, 25, 15-23.

[28] Khan, F.U.H., Tahir, A.R. and Yule, I.J. (2001) Intrinsic Implication of Different Tillage Practices on Soil Penetration Resistance and Crop Growth. International Journal of Agriculture and Biology, 3, 23-26.

[29] Mkhabela, M.S., Mkhabela, M.S. and Pali-Shikhulu, J. (2001) Response of Maize (Zea mays L.) Cultvars to Different Levels of Nitrogen Application in Swaziland. 7th Eastern and Southern Africa Regional Maize Conference, Nairobi, 11-15 February 2001, 377-381.

[30] Ghumman, B.S. and Sur, H.S. (2001) Tillage and Residue Management Effects on Soil Properties and Yields of Rainfed Maize and Wheat in a Subhumid Subtropical Climate. Soil \& Tillage Research, 58, 1-10. http://dx.doi.org/10.1016/S0167-1987(00)00147-1

[31] Ahmad, I. (1989) The Effect of Phosphorus Application in Different Proportions with Nitrogen on the Growth and Yield of Maize. M.Sc. (Hons) Thesis, Department of Agronomy, University of Agriculture, Faisalabad.

[32] Marwat, K.B., Arif, M. and Khan, M.A. (2007) Effect of Tillage and Zinc Application Methods on Weeds and Yield of Maize. Pakistan Journal of Botany, 39, 1583-1591.

[33] Sabir, M., Ahmad, R. and Shahzad, M.A. (2000) Effect of Nitrogen and Phosphrous on Yield and Quality Parameters of Two Hybrid of Maize (Zea mays L.). Agricultural Research, 38, 339-346. 